\title{
Interpreting Relationships between Soil Variables and Soybean Iron Deficiency using Factor Analysis
}

\author{
A. M. Liesch \\ D. A. Ruiz Diaz* \\ D. B. Mengel \\ K. L. Roozeboom \\ Dep. of Agronomy \\ Kansas State Univ. \\ Manhattan, KS 66506
}

Iron chlorosis in soybean [Glycine max (L.) Merr.] can be difficult to predict and often depends on various soil factors. The objective of this study was to determine the underlying soil factors that are conducive to Fe chlorosis in soybean using a statistical factor analysis. This study was conducted at seven locations in western Kansas with intensive soil sampling to investigate the relationships between soil variables and the incidence of Fe chlorosis. The soil variables measured were $\mathrm{pH}, \mathrm{P}, \mathrm{Fe}$, organic matter $(\mathrm{OM}), \mathrm{Ca}, \mathrm{Mg}$, electrical conductivity (EC), $\mathrm{NO}_{3}-\mathrm{N}$, and calcium carbonate equivalent (CCE). Factor analysis was performed using the Varimax rotation and the Heywood convergence to obtain the best possible relationships. The factors were deemed significant if the Eigenvalues were $>1$. The factor analysis showed that two underlying factors can be selected to explain the incidence of Fe chlorosis in soybean. These factors are "plant chlorosis" (Factor 1) and "soil available $\mathrm{Fe}^{\prime \prime}$ (Factor 2). With regression analysis, these underlying factors were indicative of the chlorophyll meter (CM) readings at the V3 and V6 growth stages and in the grain yield (GY). However, soybean management practices, such as variety selection and the use of seed-applied Fe fertilizers were shown to affect the relationship between latent factors (from factor analysis) and soybean response. When seed-applied Fe fertilizers are used with tolerant and nontolerant soybean varieties, the overall effect of the undelaying soil factors seems irrelevant to soybean response.

Abbreviations: CM, SPAD chlorophyll meter reading;; EC, electrical conductivity; EDDHA, ethylene diamine-N, $\mathrm{N}^{\prime}$-bis (hydroxy phenyl) acetic acid; GY, grain yield; OM, organic matter.

I

ron is a vital component in microbial health, bacterial nodulation, plant photosynthetic processes and physiological growth. However, various interactions take place in the soil that can make Fe unavailable for uptake and plant use, generating often severe Fe deficiency chlorosis. Conditions that cause Fe chlorosis are complex, and can be due to several soil, climatic, and plant factors. Soil chemical nature and nutrient availability can make Fe unavailable in many ways. Soil pH, for instance, can create low $\mathrm{Fe}$ availability for plant uptake, as the solubility of $\mathrm{Fe}^{3+}$ decreases 1000 times, and $\mathrm{Fe}^{2+}$ solubility decreases 100 times, for every unit increase in soil pH (Lindsay and Schwab, 1982). Free carbonates and bicarbonates in soils (Inskeep and Bloom, 1984), and calcareous parent materials (Miller et al., 1984) also contribute to the decrease in plant available Fe. Other factors, such as lower OM or a lack of natural chelates, can prevent the Fe in soil from moving to the roots (Lindsay and Schwab, 1982).

Not only do single soil variables negatively impact Fe uptake, several interactions between nutrients occurs when the supply of one nutrient affects the

Soil Sci. Soc. Am. J. 76:1311-1318

doi:10.2136/sssaj2011.0379

Contribution no. 12-005-J from the Kansas Agricultural Experiment Station.

Received 4 Nov. 2011.

*Corresponding author (ruizdiaz@ksu.edu).

(C) Soil Science Society of America, 5585 Guilford Rd., Madison WI 53711 USA

All rights reserved. No part of this periodical may be reproduced or transmitted in any form or by

any means, electronic or mechanical, including photocopying, recording, or any information storage and retrieval system, without permission in writing from the publisher. Permission for printing and for reprinting the material contained herein has been obtained by the publisher. 
absorption and utilization of other nutrients in the soil and in the plant (Fageria, 2001). Iron is an essential component for a number of critical enzymes, including those involved in photosynthesis and N fixation (Rotaru and Sinclair, 2009). Yet Fe has antagonistic relationships with many other cations, and Fe deficiency may inhibit the adsorption of some elements (Madero et al., 1992). Therefore, the interactions that create Fe chlorosis can be complex. In a series of studies in western Minnesota, chlorosis has been reported to be associated with higher soil Mg levels, higher $\mathrm{Mg} / \mathrm{Ca}$ ratios, plant $\mathrm{P}$ levels, high soil moisture, low soil temperature, and higher bicarbonate levels (Inskeep and Bloom, 1984, 1986; Bloom and Inskeep, 1986). Legumes appear to be especially vulnerable to $P$ and Fe deficiencies because of their role in supporting symbiotic N fixation (Rotaru and Sinclair, 2009; O'Hara et al., 1988). Plants exude $\mathrm{H}+$ into the rhizosphere and acidify the soil in the area (Marschner, 1995). However, in the presence of Fe and $\mathrm{P}$ deficiency, plants often have the ability to increase $\mathrm{H}+$ root exudates that can acidify the rhizosphere, and increase the quantity of both of these nutrient in the plant (Gardner et al., 1983).

Management practices such as $\mathrm{Fe}$ fertilizer application and lowering the soil $\mathrm{pH}$ can increase Fe uptake, which can remediate chlorosis (Rai, 1988). Several management practices are recommended to remediate effects of Fe deficiency. The selection of a tolerant variety is one of the most widely recommended methods (Goos and Johnson, 2000; Wiersma 2010). However, Helms et al. (2010) suggested that the tolerant variety is not necessarily the best selection, and is often better to plant a variety with high yield potential outside of zones with severe Fe deficiency. Mortvedt (1991) found that adding $\mathrm{FeSO}_{4}$ to the furrow increased yields and reduced chlorosis, however inorganic Fe sources quickly become unavailable, and may not be economical. Foliar Fe application, especially of chelated forms, has been inconsistent, being successful at some locations in reducing signs of chlorosis (Goos and Johnson, 2000) and increasing yield in some cases (Penas et al., 1990). However it has been unsuccessful at other locations (Lingenfelser et al., 2005). Another suggested method is to apply chelated Fe sources to the soil, or seed-applied, which has been successful in some cases (Karkosh et al., 1988).

In the United States, significant work has been performed on Fe chlorosis in the calcareous glacial lobes originating from the calcareous shale bedrock under the Keewatin Ice Dome

Table 1. County and soil classification at seven irrigated locations in Kansas.

\begin{tabular}{|c|c|c|c|}
\hline \multirow{2}{*}{ Location } & \multirow{2}{*}{ County } & \multicolumn{2}{|r|}{ Predominant soil } \\
\hline & & Series & Taxonomic classification \\
\hline & & & $\underline{2009}$ \\
\hline 1 & Finney & Ulysses & Ulysses fine-silty, mixed, superactive, mesic Aridic Haplustolls \\
\hline 2 & Lane & Richfield & Richfield fine, smectitic, mesic Aridic Argiustolls \\
\hline 3 & Lane & Richfield & $\begin{array}{l}\text { Richfield fine, smectitic, mesic Aridic Argiustolls } \\
\underline{2010}\end{array}$ \\
\hline 4 & Thomas & Ulysses & Ulysses fine-silty, mixed, superactive, mesic Aridic Haplustolls \\
\hline 5 & Thomas & Ulysses & Ulysses fine-silty, mixed, superactive, mesic Aridic Haplustolls \\
\hline 6 & Finney & Ulysses & Ulysses fine-silty, mixed, superactive, mesic Aridic Haplustolls \\
\hline 7 & Lane & Richfield & Richfield fine, smectitic, mesic Aridic Argiustolls \\
\hline
\end{tabular}

(Leverett, 1932), including the Des Moines Lobe (Rogovska et al., 2007) and the Red River Dome (Inskeep and Bloom, 1986; Franzen and Richardson, 2000). In these regions, Fe chlorosis usually occurs in areas of depressions in the landscape or in the potholes left behind by masses of melting ice. These depression areas usually hold water temporarily and the carbonates in the surrounding landscape leach into these low spots (Rogovska et al., 2007). Because water movement can be unpredictable, there is often a high spatial variability of Fe chlorosis within a field. In addition, different annual weather patterns can make chlorosis more or less prevalent each year (Godsey et al., 2003; Naeve and Rehm, 2006), with significantly different effects under different soil conditions.

In the Great Plains region of the United States, including western Kansas, such potholes and depressions are less common. The loess in western Kansas is also calcareous in nature, but these potholes do not exist because the soils are more uniformly wind deposited. Moreover, even though there are areas in a field that can be more severely affected, Fe chlorosis can impact entire fields. In comparison to other regions, the soils in this region are fairly uniform, thus, the main soil properties that create Fe chlorosis are likely different.

Research on soybean Fe chlorosis has been conducted for several years, and studies have suggested that various soil factors are associated with $\mathrm{Fe}$ chlorosis. Earlier studies have focused on individual key factors that determine chlorosis, including soil $\mathrm{pH}, \mathrm{CCE}, \mathrm{OM}$, and the interaction of Fe with other nutrients, especially N and P (Bloom et al., 2011). However, previous studies have not evaluated Fe chlorosis with a multivariate approach, including expected interactions of the soil conditions in addition to the effect of potential production management systems for $\mathrm{Fe}$ chlorosis. Multivariate analysis is an exploratory tool that is useful in determining the simultaneous observation and analysis of more than one variable in a multidimensional space. Factor analysis is used to find underlying factors that one variable alone cannot measure. The objective of this study was to determine the underlying factors and multi-linear models that are associated with Fe chlorosis in soybean in the Great Plains region.

\section{MATERIALS AND METHODS}

Trials were conducted under irrigated conditions at locations with a history of Fe deficiency in soybean. The studies were conducted at three locations in 2009 and four locations in new fields in 2010 for a total of seven locations (Liesch et al., 2011). Descriptions of each location are provided in Table 1, and the soil chemical factors are given in Table 2. Soybean were planted at a 0.76-m row spacing at all locations. At each location, a total of 48 plots ( 4 rows wide and $7.6 \mathrm{~m}$ long) were compositely sampled to evaluate the soil variably and Fe chlorosis expression in soybean. Approximately 10 to 12 cores (subsamples) were collected 
from each plot. The soil samples were collected from each plot at a depth of 0 to $15 \mathrm{~cm}$ and were analyzed for $\mathrm{pH}$ using a $1: 1$ soil/water ratio (Watson and Brown, 1998); soil test phosphorus (STP) was determined with the Mehlich-3 method (Frank et al., 1998). Iron diethylene-triamine-penta-acetate (DTPA) extraction was performed using the method of Whitney (1998a) and the extract was analyzed using an ICP spectrometer. Calcium and magnesium was determined by ammonium acetate extraction (Warncke and Brown, 1998). Soil organic matter (OM) was measured using the Walkley-Balck method (Combs and Nathan, 1998). The calcium carbonate equivalent (CCE) was measured by adding dilute $\mathrm{HCl}$ to the soil and measuring the $\mathrm{CO} 2$ gas displacement a method adapted from that of Huang et al. (2007). Electrical conductivity (EC) was measured using saturated paste method (Whitney, 1998b). The subsurface soil $\mathrm{pH}$ and DTPA-Fe were also measured at a depth of 15 to $30 \mathrm{~cm}$. Nitrate-N was measured at a depth of 0 to $60 \mathrm{~cm}$ with a $1 \mathrm{M}$ $\mathrm{KCl}$ extraction (Gelderman and Beegle, 1998) using a rapid flow analyzer (Alpkem, College Station, TX).

At each location, CM readings were recorded with a SPAD 502 (Minolta, Ramsey, NJ) for the uppermost fully developed leaflets. Twenty readings were averaged into one value at the V3 growth stage (Pedersen, 2004). A second set of CM readings at the V6 growth stage were used to monitor the chlorosis level later in the season. Grain yield was determined by harvesting the two center rows using a plot combine, or by cutting plants from the two center rows of each plot and threshing with a stationary thresher. Grain moisture was measured by weighing approximately $500 \mathrm{~g}$ of field-moist grain and weighing the grain again after drying it at $65^{\circ} \mathrm{C}$ for $6 \mathrm{~d}$. The moisture content was recorded and used to adjust the grain yields to moisture of $130 \mathrm{~g} \mathrm{~kg}^{-1}$.

Different management strategies, including the selection of soybean variety and seed-applied Fe fertilizer were established in a complete factorial combination. Four varieties of Maturity Groups II or III were selected with varying Fe chlorosis ratings during the 2 $\mathrm{yr}$ of the study. Two varieties were selected to represent very good tolerance to $\mathrm{Fe}$ chlorosis (Asgrow2906 in 2009 and Asgrow 3039 in 2010) and low tolerance (Asgrow 3205 in 2009 and Asgrow 3005 in 2010). The treatments at each location included two different varieties (tolerant and susceptible to Fe deficiency) and two seed-applied Fe fertilizers (with and without seed-applied Fe fertilizer) and using a dry $6 \%$ Fe-ethylene diamineN,N'-bis (hydroxy phenyl) (EDDHA). For the seed-applied Fe fertilizer, a slurry mix of Fe-EDDHA $(6 \% \mathrm{Fe})$ product and water was applied at a rate totaling $0.2 \mathrm{~kg} \mathrm{Fe} \mathrm{ha}^{-1}$. The seeds were air dried before planting.

\section{Statistical Analysis}

Pearson correlation coefficients between the soil and plant measurements were calculated using the CORR procedure in SAS (SAS Institute, 2010). For the factor analysis, all of the soil variables were standardized with a mean equal to 0 and a standard deviation equal to 1 . Normality tests were conducted using PROC UNIVARIATE in SAS (SAS Institute, 2010), data followed a normal distribution and transformation was unnecessary. The factors were extracted with the FACTOR procedure, using the method of Maximum Likelihood, and the Heywood procedure, which maximizes variables at a correlation of 1 (Johnson, 1998). The Varimax procedure was used as an oblique orthogonal rotation method to determine the best fit. The rotation of factors is a way to gain a more meaningful estimate of the factors to obtain a linear transformation (Hair et al., 1987; Johnson, 1998).

Groups of correlated variables were defined using factor analysis. The measured variables with relatively high factor loadings were selected from each factor. When two or more variables are grouped in a latent variable, this suggests a possible common underlying factor that makes them vary together. The signs of the factor loadings provide information of how these variables relate when representing the common factor (Everitt and Dunn, 2001). Variables with large factor loadings are expected to represent a common factor; however, there are no established guidelines that help decide what can be considered as large factor loading. Therefore, the criteria used to select a specific variable included both the value of the coefficients and its relative difference from other coefficients in the factor.

Table 2. Means and standard deviations of selected soil properties at seven locations. Samples were collected from $\mathbf{4 8}$ small plots at each location.

\begin{tabular}{|c|c|c|c|c|c|c|c|c|c|c|c|}
\hline \multirow{3}{*}{ Location } & \multicolumn{11}{|c|}{ Sampling depth } \\
\hline & \multicolumn{8}{|c|}{$0-15 \mathrm{~cm}$} & \multicolumn{2}{|c|}{$15-30 \mathrm{~cm}$} & \multirow{2}{*}{$\frac{0-60 \mathrm{~cm}}{\mathrm{NO}_{3}-\mathrm{N}}$} \\
\hline & $\mathrm{pH}$ & STPt & Fe‡ & $\mathrm{Ca}$ & Mg & CCE§ & OMף & EC\# & $\mathrm{pH}$ & Fe‡ & \\
\hline & & \multicolumn{4}{|c|}{$\longrightarrow \mathrm{mg} \mathrm{kg}^{-1}$} & \multicolumn{2}{|c|}{$-\mathrm{g} \mathrm{kg}^{-1}-$} & $\mathrm{m} \mathrm{S}^{-1}$ & \multicolumn{3}{|c|}{$-\mathrm{mg} \mathrm{kg}^{-1}$} \\
\hline \multicolumn{12}{|c|}{ Mean } \\
\hline 1 & 8.2 & 28.5 & 1.9 & 4116 & 467 & 93 & 21.7 & 0.91 & 8.3 & 2.3 & 17.20 \\
\hline 2 & 8.3 & 78.1 & 2.8 & 4428 & 710 & 60 & 19.4 & 0.59 & 8.3 & 2.1 & 6.97 \\
\hline 3 & 8.1 & 68.7 & 3.3 & 4467 & 643 & 44 & 18.0 & 0.78 & 8.3 & 1.9 & 8.81 \\
\hline 4 & 8.3 & 53.4 & 1.6 & 4827 & 317 & 97 & 21.9 & 0.59 & 8.5 & 1.4 & 7.02 \\
\hline 5 & 8.5 & 66.4 & 1.4 & 4734 & 330 & 138 & 18.5 & 0.54 & 8.6 & 1.6 & 5.08 \\
\hline 6 & 8.2 & 22.0 & 1.8 & 3824 & 644 & 114 & 20.5 & 1.00 & 8.3 & 2.0 & 14.60 \\
\hline 7 & 8.1 & 109.0 & 1.8 & 5194 & 554 & 140 & 24.8 & 0.64 & 8.5 & 1.8 & 11.50 \\
\hline \multicolumn{12}{|c|}{$\underline{\text { Standard deviation }}$} \\
\hline 1 & 0.13 & 2.9 & 0.4 & 420 & 67.3 & 22.8 & 1.6 & 0.21 & 0.16 & 0.3 & 6.42 \\
\hline 2 & 0.12 & 10.0 & 0.5 & 301 & 42.3 & 38.9 & 2.4 & 0.11 & 0.11 & 0.3 & 1.47 \\
\hline 3 & 0.12 & 13.1 & 0.2 & 229 & 41.4 & 42.7 & 1.7 & 0.18 & 0.10 & 0.2 & 1.92 \\
\hline 4 & 0.14 & 15.1 & 0.2 & 174 & 19.1 & 34.5 & 2.5 & 0.10 & 0.14 & 0.3 & 2.24 \\
\hline 5 & 0.16 & 38.9 & 0.2 & 178 & 19.7 & 30.3 & 2.0 & 0.08 & 0.06 & 0.1 & 1.31 \\
\hline 6 & 0.14 & 7.5 & 0.2 & 404 & 36.4 & 21.2 & 2.2 & 0.22 & 0.11 & 0.1 & 4.25 \\
\hline 7 & 0.22 & 11.0 & 0.1 & 162 & 31.5 & 21.8 & 1.9 & 0.07 & 0.08 & 0.1 & 3.54 \\
\hline \multicolumn{12}{|c|}{ † STP, Soil test Mehlich phosphorus. } \\
\hline \multicolumn{12}{|c|}{ ‡ DTPA Fe. } \\
\hline \multicolumn{12}{|c|}{$\S$ CCE, Calcium carbonate equivalent. } \\
\hline - OM, Org & & & & & & & & & & & \\
\hline
\end{tabular}


Table 3. Pearson correlation coefficients between the individual soil and plant variables across locations. $t$

\begin{tabular}{|c|c|c|c|c|c|c|c|c|c|c|c|c|c|c|}
\hline Variable & CM-V3‡ & CM-V6‡ & GY§ & $\mathrm{pH}$ & STP & $\mathrm{Fe}$ & OM & $\mathrm{Ca}$ & $\mathrm{Mg}$ & EC & $\mathrm{NO}_{3}-\mathrm{N}$ & CCE\# & pH (15-30) & Fe (15-30) \\
\hline CM-V3‡ & 1 & & & & & & & & & & & & & \\
\hline CM-V6‡ & $0.69 *$ & 1 & & & & & & & & & & & & \\
\hline GY§ & $0.71^{*}$ & $0.71 *$ & 1 & & & & & & & & & & & \\
\hline $\mathrm{pH}$ & -0.46 & $-0.48^{*}$ & $-0.48^{*}$ & 1 & & & & & & & & & & \\
\hline STP & 0.01 & -0.04 & $0.14^{*}$ & $-0.34 * 1$ & & & & & & & & & & \\
\hline $\mathrm{Fe}$ & $0.45^{*}$ & $0.38^{*}$ & $0.64^{*}$ & $-0.65^{*}$ & $0.65^{*}$ & 1 & & & & & & & & \\
\hline OM & $-0.17^{*}$ & $-0.18^{*}$ & $-0.41^{*}$ & -0.02 & $0.24^{*}$ & $-0.21^{*}$ & 1 & & & & & & & \\
\hline $\mathrm{Ca}$ & $-0.51^{*}$ & $-0.52^{*}$ & $-0.64^{*}$ & $0.61 *$ & -0.12 & $-0.74 *$ & $0.37^{*}$ & 1 & & & & & & \\
\hline Mg & -0.03 & $0.33^{*}$ & -0.07 & $0.22 *$ & $-0.22 *$ & $-0.48^{*}$ & $0.23 *$ & $0.50^{*}$ & 1 & & & & & \\
\hline EC $\Phi$ & 0.12 & $0.35^{*}$ & -0.07 & 0.04 & $-0.43^{*}$ & $-0.36^{*}$ & $0.28^{*}$ & 0.08 & $0.51 *$ & 1 & & & & \\
\hline $\mathrm{NO}_{3}-\mathrm{N}$ & $0.21^{*}$ & $0.41 *$ & -0.02 & $-0.14^{*}$ & $-0.27^{*}$ & $-0.21^{*}$ & $0.38^{*}$ & -0.01 & $0.36^{*}$ & $0.72 *$ & 1 & & & \\
\hline CCE\# & $-0.53^{*}$ & $-0.46^{*}$ & $-0.71^{*}$ & $0.29 *$ & -0.08 & $-0.49^{*}$ & $0.41^{*}$ & $0.38^{*}$ & 0.05 & $0.21 *$ & $0.22 *$ & 1 & & \\
\hline $\mathrm{pH}(15-30)$ & $-0.64 *$ & $-0.67^{*}$ & $-0.72 *$ & $0.72 *$ & $-0.26^{*}$ & $-0.69 *$ & 0.13 & $0.66^{*}$ & 0.10 & 0.02 & $-0.16^{*}$ & $0.48^{*}$ & 1 & \\
\hline Fe (15-30) & $0.43^{*}$ & $0.34 *$ & $0.56^{*}$ & $-0.65^{*}$ & $0.59 *$ & $0.95 *$ & $-0.19^{*}$ & $-0.78^{*}$ & $-0.56^{*}$ & $-0.34 *$ & $-0.15^{*}$ & $-0.38^{*}$ & $-0.68^{*}$ & 1 \\
\hline \multicolumn{15}{|c|}{ * Significant at $P \leq 0.05$} \\
\hline \multicolumn{15}{|c|}{ † All samples were collected at a depth of 0 to $15 \mathrm{~cm}$, except for the additional $\mathrm{pH}$ and Fe at 15 to $30 \mathrm{~cm}$ and $\mathrm{NO}_{3}-\mathrm{N}$ at 0 to $60 \mathrm{~cm}$. } \\
\hline \multicolumn{15}{|c|}{ ₹ CM-V3, chlorophyll meter reading at the V3 growth stage; CM-V6, chlorophyll meter reading at the V6 growth stage. } \\
\hline \multicolumn{15}{|c|}{$\S$ GY, Grain yield. } \\
\hline \multicolumn{15}{|c|}{ I EC, Electrical conductivity. } \\
\hline
\end{tabular}

The underlying factor variables were accepted if the eigenvalues for the correlation matrix were larger than one using standardized variables (Johnson, 1998). The new variables are known as latent variables; they are not directly measureable, but they represent underlying factors that may be a combination of variables (Terra et al., 2006; Kaspar et al., 2004). The PROC REG procedure in SAS was used for stepwise linear regression models using the new variables from the factor analysis (latent factors) of the correlated soil variables to explain the plant CM readings and GY for all of the management systems (varieties and seed-applied fertilizer treatment combinations) (Cox et al., 2003).

\section{RESULTS AND DISCUSSION}

The mean values and variability of the measured soil parameters across locations are presented in Table 2 . The soil $\mathrm{pH}$ values and CCE were high for all of the locations, with a generally low DTPA-extractable Fe. Values of these parameters often lead to high incidences of Fe chlorosis. The correlation coefficients were determined between the crop and soil parameters (Table 3). The correlation analysis of the soil properties and plant parameters generated 72 significant $(P \leq 0.05)$ correlations from a total of 98 pairs. The chlorophyll meter readings at the V3 (CM-V3) and V6 (CM-V6) growth stages showed a positive correlation $(P \leq 0.05)$ with the grain yield, soil Fe (at the depths of $0-15$ and $15-30 \mathrm{~cm}$ ), and soil $\mathrm{NO}_{3}-\mathrm{N}$. In contrast, the $\mathrm{CM}$ readings showed a negative correlation with the soil $\mathrm{pH}$ (at the depths

Table 4. Eigenvalues, proportions, and cumulative variances explained by factor analysis.

\begin{tabular}{lcccc} 
Factors & Eigenvalue & Difference & Proportion & Cumulative \\
\hline 1 & 10.25 & 5.45 & 0.59 & 0.59 \\
2 & 4.80 & 1.76 & 0.28 & 0.86 \\
\hline
\end{tabular}

of $0-15$ and $15-30 \mathrm{~cm}), \mathrm{OM}, \mathrm{Ca}$, and CCE. The GY showed a positive correlation with the soil test $\mathrm{P}$ and extractable $\mathrm{Fe}$ (at the depths of $0-15$ and $15-30 \mathrm{~cm}$ ). Negative correlations were found between the GY and soil pH (at the depths of 0-15 and 15-30 cm), CCE, OM, and Ca.

The soil attributes with the highest positive correlation occurred for the surface $(0-15 \mathrm{~cm})$ extractable Fe and $\mathrm{pH}$ vs. the subsurface $(15-30 \mathrm{~cm}) \mathrm{Fe}$ and $\mathrm{pH}$, respectively. High positive correlations were also found for the Fe vs. the P, EC and $\mathrm{NO}_{3}-\mathrm{N}$; however, the highest negative correlations were found for the $\mathrm{Fe}$ vs. the $\mathrm{pH}$, $\mathrm{Ca}$, and CCE (Table 3).

Once the factor analysis was performed, there were two underlying factors that were determined by the varimax rotation to be significant (Table 4). Soil test P was the only major contributor in the third factor, and therefore STP was added to the regression equation as a stand-alone variable for further analysis. The eigenvalues from the covariance analysis indicated that the first two factors accounted for $86 \%$ of the variance of data (Table 4). The first factor accounted for $59 \%$ of the total variance, and the second factor accounted for an additional $28 \%$.

The first latent factor (Factor 1) was identified as "plant chlorosis", as all of these soil factors can potentially affect plant pigmentation. The variables with high factor loadings included the $\mathrm{EC}, \mathrm{NO}_{3}-\mathrm{N}, \mathrm{Ca}$, and subsurface $\mathrm{Fe}$ and $\mathrm{pH}$ (Table 5). The negative correlation of the soil $\mathrm{Fe}(15-30 \mathrm{~cm})$ and $\mathrm{pH}(15-30 \mathrm{~cm})$ at lower depth may be due to a decrease in the measured extractable Fe with an increase in the soil $\mathrm{pH}$. The second latent variable (Factor 2) was identified as "soil available Fe" with the extractable Fe showing the highest loading. Extractable Fe showed a negative correlation with the CCE and $\mathrm{pH}(15-30 \mathrm{~cm})$ and a positive correlation with the $\mathrm{Mg}$. There have been previous studies that indicated no correlation between DTPA extractable soil Fe levels and soybean greenness and yield (Naeve and Rehm, 2006; 
Bloom et al., 2011). However, in these situations, the DTPAextractable soil Fe levels may be much higher in concentration, indicating that other factors such as internal plant physiology, or other soil nutrients and properties may be influencing Fe availability. Furthermore, DTPA-extractable Fe test was originally developed for soil from neutral to alkaline soils with low concentrations of Fe (O'Connor 1988). Similar to the results of Franzen and Richardson (2000) our data revealed that the DTPA Fe was negatively correlated with the $\mathrm{pH}$ and calcium carbonate level.

In Factor 2, the Mg levels had a positive relationship with the surface Fe. According to Loeppert and Hallmark (1985), the $\mathrm{Mg}$ content in the soil solution has also been found to correlate positively with the soil-extractable Fe. On the other hand, Morris et al. (1990) found that soil Mg content was negatively correlated with plant leaf chlorophyll content, and contributed this to $\mathrm{Mg}$ influence on calcite solubility, or the ionic strength of their particular solution. Several groups of correlated variables were identified with the factor analysis; however, this may not always explain soybean GY response and Fe chlorosis development. Models relating the two latent variables and STP as stand-alone variable with the $\mathrm{CM}$ readings at the $\mathrm{V} 3$ and $\mathrm{V} 6$ growth stages and the GY are listed in Table 6. This analysis also determined whether the calculated factors as well as STP were related to our measured soybean response parameters and how this relationship may be affected by different management practices. This determination can help us to evaluate how underlying factors may be relevant under different soybean management conditions in an environment prone to Fe deficiency.

Without seed-applied Fe fertilizer, both of the soybean varieties (tolerant and nontolerant) were highly influenced by the two factors for both of the agronomic parameters (CM readings and GY). With regard to the chlorophyll meter readings at V3 (CM-V3) for the nontolerant variety, Factor 2 explained nearly double the variability (defined by the coefficients in the linear analysis) of Factor 1 . In the tolerant variety, however, Factor 1 explained 1.2 times more variability than Factor 2 (Table 6). This result suggests that the $\mathrm{CM}$ readings at V3 in the tolerant variety were less influenced by Factor 2 (soil $\mathrm{Fe}, \mathrm{Mg}, \mathrm{CCE}$, and subsurface $\mathrm{pH}$ ). Furthermore, the contribution of STP as stand-alone variable was negligible. These factors only accounted for 43 to $45 \%$ of the variability in the CM values (Table 6). This indicates that other variables that were not necessarily measured may account for a high amount of variability. However, later in the season at V6, the two factors and STP explained between 76 and $83 \%$ of the variation in the CM lev-
Table 5. Rotated factor loadings determined for measured variables to create the latent variables.

\begin{tabular}{|c|c|c|}
\hline Variables & Factor 1 & Factor 2 \\
\hline ECt & $0.76 \neq$ & 0.07 \\
\hline $\mathrm{NO}_{3}-\mathrm{N}$ & $0.73 \ddagger$ & -0.09 \\
\hline $\mathrm{Fe}$ & 0.08 & $0.98+$ \\
\hline $\mathrm{pH}$ & -0.40 & -0.33 \\
\hline STP & -0.41 & 0.23 \\
\hline $\mathrm{Ca}$ & $-0.70 \neq$ & -0.18 \\
\hline Mg & 0.40 & $0.63 \ddagger$ \\
\hline OM & 0.18 & -0.30 \\
\hline CCE & -0.05 & $-0.64 \ddagger$ \\
\hline $\mathrm{Fe}(15-30) \S$ & $0.60 \neq$ & 0.43 \\
\hline $\mathrm{pH}(15-30) \S$ & $-0.63 \ddagger$ & $-0.51 \neq$ \\
\hline
\end{tabular}

† EC, electrical conductivity; STP, soil test Mehlich phosphorus; OM, organic matter; CCE, calcium carbonate equivalent.

₹ Indicates variables with high factor loadings selected from each factor to create latent variables.

$\S$ Subsurface samples from the 15 - to $30-\mathrm{cm}$ depth.

els. At this stage in crop development, Factor $1\left(\mathrm{EC}, \mathrm{NO}_{3}-\mathrm{N}\right.$, $\mathrm{Ca}$, and subsurface $\mathrm{pH}$ and $\mathrm{Fe}$ ) in both of the varieties was more influential. Soil test P was not statistically significant (Table 6). Yield was most impacted by Factor 2 (soil Fe, Mg, CCE, and subsurface $\mathrm{pH}$ ). Factor 2 explained more than twice the amount of variation in yield compared with Factor 1 in the model for both of the varieties. Although SPT impacted yield response, the amount of variation explained by this variable was very low when compared to Factors 1 and 2.

The importance of the calculated factors was different with the seed-applied Fe fertilizer. In the nontolerant variety, only STP significantly affected the CM at the V3 growth stage. The tolerant variety with seed coating showed that Factor 1 and STP was not significant, but Factor 2 (soil Fe, Mg, CCE, and subsurface $\mathrm{pH}$ ) was significant, which indicates that there are internal varietal differences in how these soybean varieties process $\mathrm{Fe}$,

Table 6. Effect of soybean management (tolerant and nontolerant varieties and seed-applied Fe fertilizer) on the coefficients of factor regression for chlorophyll meter (CM) readings at the V3 and V6 growth stages and grain yield.

\begin{tabular}{|c|c|c|c|c|c|c|c|c|}
\hline \multirow{2}{*}{ Management } & \multirow{2}{*}{ Intercept } & \multicolumn{3}{|c|}{ Coefficient } & \multicolumn{3}{|c|}{ Significance } & \multirow{2}{*}{$R^{2}$ Value } \\
\hline & & Factor 1 & Factor 2 & STP & Factor 1 & Factor 2 & STP & \\
\hline & & & & & \multicolumn{3}{|c|}{$-P<F-$} & \\
\hline \multicolumn{9}{|c|}{ CM readings at the $V 3$ stage } \\
\hline Nontolerant & 28.13 & 1.26 & 2.51 & -0.020 & 0.010 & $<0.001$ & 0.161 & 0.43 \\
\hline Nontolerant with seed-Fe & 31.69 & 0.84 & -0.96 & 0.034 & 0.076 & 0.063 & 0.004 & 0.13 \\
\hline Tolerant & 30.60 & 2.06 & 1.65 & -0.032 & $<0.001$ & 0.001 & 0.012 & 0.45 \\
\hline Tolerant with seed-Fe & 34.79 & 0.58 & -1.52 & -0.003 & 0.162 & $<0.001$ & 0.669 & 0.30 \\
\hline \multicolumn{9}{|c|}{$\mathrm{CM}$ readings at the $\mathrm{V} 6$ stage } \\
\hline Nontolerant & 28.58 & 8.70 & 8.06 & -0.019 & $<0.001$ & $<0.001$ & 0.390 & 0.83 \\
\hline Nontolerant with seed-Fe & 31.76 & 4.79 & 5.16 & 0.001 & $<0.001$ & $<0.001$ & 0.965 & 0.69 \\
\hline Tolerant & 30.09 & 8.07 & 6.36 & -0.002 & $<0.001$ & $<0.001$ & 0.892 & 0.76 \\
\hline Tolerant with seed-Fe & 34.63 & 5.72 & 2.07 & -0.009 & $<0.001$ & $<0.001$ & 0.501 & 0.67 \\
\hline \multicolumn{9}{|c|}{ Grain yield } \\
\hline Nontolerant & 1.79 & 0.35 & 1.12 & -0.007 & $<0.001$ & $<0.001$ & 0.010 & 0.79 \\
\hline Nontolerant with seed-Fe & 2.60 & 0.05 & 1.18 & -0.006 & 0.662 & $<0.001$ & 0.060 & 0.61 \\
\hline Tolerant & 1.80 & 0.30 & 1.00 & -0.009 & $<0.001$ & $<0.001$ & 0.001 & 0.65 \\
\hline Tolerant with seed-Fe & 2.39 & -0.29 & 1.29 & -0.007 & 0.170 & $<0.001$ & 0.006 & 0.75 \\
\hline
\end{tabular}


which may be expected based on the variety selection. It could be that one particular variety maximized the potential CM readings for the soil type, or it could be an indicator that the tolerant variety may be more sensitive to nutrient imbalances once an adequate Fe concentration was met at the early growth stages.

At V6, the nontolerant variety was more impacted by Factor 2 in the presence of the seed-applied Fe fertilizer, and no significant effect of STP. For the tolerant and nontolerant varieties with seed-applied Fe fertilizer, only Factor 2 significantly affected the yield. This result suggests that under adequate amounts of Fe provided by fertilizer application, neither variety showed a relationship with Factor 1 (EC, $\mathrm{NO}_{3}-\mathrm{N}, \mathrm{Ca}$, and subsurface $\mathrm{pH}$ and Fe). Helms et al. (2010) have stated that planting a tolerant cultivar may reduce the prevalence of Fe chlorosis but may not maximize yields in the field. In this study, the nontolerant variety may have had the higher yield potential under good growing conditions, and when Fe fertilizer is applied to this variety, the yield can be maximized.

The values of $R^{2}$ ranged from 0.13 to 0.83 for all models, and all of the models were statistically significant except for the $\mathrm{CM}$ readings at $\mathrm{V} 3$ using a nontolerant variety with seed $\mathrm{Fe}(P$ $=0.209)$. It is likely that when the combination of nontolerant variety and seed-Fe fertilizer application is used in fields prone to Fe chlorosis, the two latent variables identified will not account for the variably in the CM readings at the V3 growth stage. With this combination of management strategies, it is likely that the variability in CM readings will be affected by other variables not measured. In the present study, when seed-applied Fe fertilizer was used, the first latent variable (Factor 1) was not significant for the CM readings at the V3 growth stage and in grain yield. We can speculate, that by using seed-applied Fe fertilizer, the underlying variables in Factor 1 will not explain the variability in the plant response.

Most coefficients from the regression analysis showed positive signs (Table 6). In this study, the first latent variable (Factor 1) contributed to an increase in the CM readings and GY. The soil $\mathrm{NO}_{3-} \mathrm{N}$ and $\mathrm{EC}$ are two variables with high relative weights, suggesting that higher soil $\mathrm{NO}_{3}-\mathrm{N}$ and $\mathrm{EC}$ increase plant greenness and GY. This possible effect of $\mathrm{NO}_{3}-\mathrm{N}$ is not always the case, as excessive levels of $\mathrm{NO}_{3}-\mathrm{N}$, both applied as a fertilizer before the season or present in the soil, have been reported to increase Fe chlorosis at high levels, especially in nontolerant varieties (Wiersma, 2010). However, with the generally low levels of soil $\mathrm{NO}_{3}-\mathrm{N}$ found in this study, and the lack of addition of a fertilizer $\mathrm{N}$ source, there appeared to be a positive effect on the plant's response. Soybean that are exclusively dependent on biological $\mathrm{N}$ fixation for $\mathrm{N}$ supply, like those in our study, can also suffer lower yields under calcareous, high $\mathrm{pH}$ situations (Caliskan et al,. 2008). Under conditions of Fe chlorosis, biological $\mathrm{N}$ fixation is often arrested (Chonkar and Chandel, 1991; Terry and Jolley, 1994), creating potential $\mathrm{N}$ deficiency. In this case, the lack of addition of $\mathrm{N}$ fertilizer, found to be beneficial to improving early soybean growth and yield (Azfa et al., 1987;
Starling et al., 1998), could contribute to soil $\mathrm{N}$ being beneficial under low $\mathrm{N}$ conditions.

Electrical conductivity and high concentrations of soluble salts in soils have generally been shown to increase chlorosis with increasing salt levels (Franzen and Richardson, 2000). These high salt levels have also been found to decrease nodule activity and $\mathrm{N}$ accumulation (Cordovilla et al., 1995). However, in our study, the EC levels were positive in the underlying Factor 1 along with soil $\mathrm{NO}_{3}-\mathrm{N}$, suggesting that the $\mathrm{EC}$ may be also related to $\mathrm{N}$ salt levels in the soil. In the North Central United States, salts are formed ephemerally through water movement and deposition, and calcic horizons are associated with long-term water movement in low areas of fields (Franzen and Richardson, 2000). In the Great Plains, the soils are well drained, and ephemeral salt deposition is a rare occurrence, as water rarely accumulates on the soil surface. The topography of this region is generally flat, and soil water movement is more likely to be even in the soil profile, except for potential subsurface limitations in some areas. The EC levels at all locations except 1 and 6 were well below $1 \mathrm{~m} \mathrm{~S}^{-1}$ (Table 2).

\section{CONCLUSIONS}

Factor analysis was successful at identifying the underlying factors that were significantly correlated to plant response. One group of soil variables (Factor 1 ) represented conditions associated with "plant chlorosis", including the soil $\mathrm{NO}_{3}-\mathrm{N}$ and the EC that contributed to the high CM readings, and $\mathrm{Ca}$ had an antagonistic effect on plant chlorosis. Factor 2 was identified as the "soil available Fe" factor, which was made up of DTPAextractable Fe and Mg levels that positively influenced Factor 2, and $\mathrm{CCE}$ and the subsurface $\mathrm{pH}$ levels that negatively impacted Factor 2.

These underlying factors were indicative of the soil chlorophyll meter readings at the V3 and V6 stages and grain yields. The seed-applied Fe fertilizer seemed to nullify the effect of both of the latent factors in the CM-V3 readings in the nontolerant variety. In the tolerant variety with seed-applied Fe, it was the "soil available Fe" factor (Factor 2) that became neutralized. Factor 1 (plant chlorosis) did not significantly affect the yield when seed-applied Fe fertilizer is used.

The multivariate factor analysis used in this study showed that the variability in soybean Fe chlorosis can be explained by a set of soil conditions. However, with the use of proper management practices, such as optimum variety selection and seed-applied Fe fertilizer, these soil factors are unsuccessful at explaining plant response. We suggest that it is likely that once the incidence of Fe chlorosis is removed (through variety selection and seedapplied Fe fertilizer), the incidence and plant response will be affected by other soil or environmental factors not measured in this study.

\section{ACKNOWLEDGMENTS}

This project was supported in part by the Kansas Soybean Commission. Appreciation is extended to Nathan Mueller and Weston Grove for assistance with field and laboratory work. 


\section{REFERENCES}

Azfa, R., G. Hardarson, F. Zapata, and S.K.A. Danso. 1987. Effects of delayed soil and foliar $\mathrm{N}$ fertilization on yield and N2 fixation of soybean. Plant Soil 97:361-368. doi:10.1007/BF02383226

Bloom, P.R., and W.P. Inskeep. 1986. Factors affecting bicarbonate chemistry and iron chlorosis in soils. J. Plant Nutr. 9:215-222. doi:10.1080/01904168609363438

Bloom, P.R., G.W. Rehm, J.A. Lamb, and A.J. Scobbie. 2011. Soil nitrate is a causative factor in iron deficiency chlorosis in soybeans. Soil Sci. Soc. Am. J. 75:2233-2241. doi:10.2136/sssaj2010.0391

Caliskan, S., I. Ozkaya, M.E. Caliskan, and M. Arslan. 2008. The effects of nitrogen and iron fertilization on growth, yield and fertilizer use efficiency of soybean in a Mediterranean-type soil. Field Crops Res. 108:126-132. doi:10.1016/j.fcr.2008.04.005

Chonkar, A.K., and A.S. Chandel. 1991. Effect of iron and molybdenum on nitrogenase activity and nitrogen fixation in soybean Glycine max grown in alluvial soils of North India. Indian J. Agron. 36:124-128.

Combs, S.M., and M.V. Nathan. 1998. Soil organic matter. In: Recommended chemical soil test procedures for the North Central Region." North Central Regional Publ. 221 (Revised). Univ. of Missouri Agric. Exp. Stn., Columbia.

Cordovilla, M.P., A. Ocana, F. Ligero, and C. Lluch. 1995. Growth and macronutrient content of fava bean plants: Effects salinity and nitrate nutrition.J.Plant Nutr. 18:1611-1628.doi:10.1080/01904169509365007

Cox, M.S., P.D. Gerard, M.C. Wardlaw, and M.J. Abshire. 2003. Variability of selected soil properties and their relationships with soybean yield. Soil Sci. Soc. Am. J. 67:1296-1302. doi:10.2136/sssaj2003.1296

Everitt, B.S., and G. Dunn. 2001. Applied multivariate data analysis. Oxford Univ. Press, New York.

Fageria, V.D. 2001. Nutrient interactions in crop pPlants. J. Plant Nutr. 24:12691290. doi:10.1081/PLN-100106981

Frank, K., D. Beegle, and J. Denning. 1998 Phosphorus. In: Recommended chemical soil test procedures for the North Central Region. North Central Regional Publ. 221 (Revised). Univ. of Missouri Agric. Exp. Stn., Columbia. p. 21-30.

Franzen, D.W., and J.L. Richardson. 2000. Soil factors affecting iron chlorosis of soybean in the Red River Valley of North Dakota and Minnesota. J. Plant Nutr. 23:67-78. doi:10.1080/01904160009381998

Gardner, W.K., D.A. Barber, and D.G. Parbery. 1983. The acquisition of phosphorus by Lupinus albus L. III. The probable mechanism by which phosphorus movement in the soil/root interface is enhanced. Plant Soil 70:107-124. doi:10.1007/BF02374754

Gelderman, R.H., and D. Beegle. 1998. Nitrate-nitrogen. In: Recommended chemical soil test procedures for the North Central Region." North Central Regional Publ. 221 (Revised).Univ. of Missouri Agric. Exp. Stn., Columbia. p. 17-21.

Godsey, C.B., J.P. Schmidt, A.J. Schlegel, R.K. Taylor, C.R. Thompson, and R.J. Gehl. 2003. Correcting Fe deficiency in corn with seed row-Applied Fe sulfate. Agron. J. 95:160-166. doi:10.2134/agronj2003.0160

Goos, R.J., and B.E. Johnson. 2000. A comparison of three methods for reducing Fe deficiency chlorosis in soybean. Agron. J. 92:1135-1139. doi:10.2134/ agronj2000.9261135x

Hair, J.F., R.E. Anderson, and R.L. Tatham. 1987. Multivariate data analysis with readings. Macmillan Publishing Company, New York.

Helms, T.C., R.A. Scott, W.T. Schapaugh, R.J. Goos, D.W. Franzen, and A.J. Schlegel. 2010. Soybean iron-deficiency chlorosis tolerance and yield decrease on Calcareous soils. Agron. J. 102:492-498. doi:10.2134/agronj2009.0317

Huang, J., P.R. Fisher, and W.R. Argo. 2007. A gasometric procedure to measure residual lime in container substrates. HortScience 42:1685-1689.

Inskeep, W.P., and P.R. Bloom. 1984. A comparative study of soil solution chemistry associated with chlorotic and nonchlorotic soybeans in western Minnesota. J. Plant Nutr. 7:513-531. doi:10.1080/01904168409363217

Inskeep, W.P., and P.R. Bloom. 1986. Effect of soil moisture on soil pCO2, soil solution bicarbonate, and Fe chlorosis in soybeans. Soil Sci. Soc. Am. J. 50:946-952. doi:10.2136/sssaj1986.03615995005000040024x

Johnson, D.E. 1998. Applied multivariate methods for data analysis. Duxbury Press, Pacific Grove, CA.

Karkosh, A.E., S.K. Walker, and J.J. Simons. 1988. Seed treatments for control of iron deficiency chlorosis of soybean. Crop Sci. 28:369-370. doi:10.2135/ cropsci1988.0011183X002800020039x

Kaspar, T.C., D.J. Pulido, T.E. Fenton, T.S. Colvin, D.L. Karlen, D.B. Jaynes, and
D.W. Meek. 2004. Relationships of corn and soybeans yield to soil and terrain properties. Agron. J. 96:700-709. doi:10.2134/agronj2004.0700

Leverett, F. 1932. Quaternary geology of Minnesota and parts of adjacent states. United States Geological Survey Professional Paper 161. U.S. Gov. Print. Office, Washington, DC.

Liesch, A.M., D.A. Ruiz Diaz, K.L. Martin, B.L. Olson, D.B. Mengel, and K.L. Roozeboom. 2011. Management strategies for increasing soybean yield on soils susceptible to iron deficiency. Agron. J. 103:1870-1877. doi:10.2134/ agronj2011.0191

Lindsay, W.L., and A.P.Schwab. 1982. The chemistryofiron in soilsanditsavailability to plants. J. Plant Nutr. 5:821-840. doi:10.1080/01904168209363012

Lingenfelser, J.E., W.T. Schapaugh, Jr., J.P. Schmidt, and J.J. Higgins. 2005. Comparison of genotype and cultural practices to control Fe deficiency chlorosis in soybean. Commun. Soil Sci. Plant Anal. 36:1047-1062. doi:10.1081/CSS-200050493

Loeppert, R.H., and C.T. Hallmark. 1985. Indigenous soil properties influencing the availability of iron in calcareous soils. Soil Sci. Soc. Am. J. 49:597-603. doi:10.2136/sssaj1985.03615995004900030013x

Madero, P., A. Pequerul, C. Perez, J. Val, and E. Mange. 1992.Specificity of iron in some aspects of soybean (Glycine max L.) physiology. In: M.A.C. Fragosa and M.L. Van Beusichem, editors, Optimization of Plant Nutrition Referred Papers from the Eight International Colloquium for the Optimization of Plant Nutrition, Lisbon, Portugal. 31 Aug.-8 Sept.1992. Kluwer Academic Publ., Dordrecht, the Netherlands. p. 497-509.

Marschner, H. 1995. Mineral nutrition of higher plants. 2nd ed. Academic Press, London.

Miller, G.W., J.C. Pushnik, and G.W. Welkie. 1984. Fe chlorosis, a world wide problem: The relation of chlorophyll biosynthesis to Fe. J. Plant Nutr. 3:767-787.

Mortvedt, J.J. 1991. Correcting iron deficiency in annual and perennial plants. Plant Soil 130:273-279. doi:10.1007/BF00011883

Morris, D.R., R.H. Loeppert, and T.J. Moore. 1990. Indigenous soil factors influencing iron chlorosis of soybean in calcareous soils. Soil Sci. Soc. Am. J. 54:1329-1336. doi:10.2136/sssaj1990.03615995005400050021x

Naeve, S.L., and G.W. Rehm. 2006. Genotype x environment interactions within Fe deficiency chlorosis-tolerant soybean genotypes. Agron. J. 98:808-814. doi:10.2134/agronj2005.0281

O'Connor, G.A. 1988. Use and misuse of the DTPA soil test. J. Environ. Qual. 17:715-718. doi:10.2134/jeq1988.00472425001700040033x

O'Hara, G.W., A. Hartzook, R.W. Bell, and J.P. Loneragan. 1988. Response of Bradyrhizobiumstrains of peanuts cultivars grow under iron stress. J. Plant Nutr. 11:843-852. doi:10.1080/01904168809363849

Pedersen, P. 2004. Soybean growth and development. PM1945. Iowa State Univ. Ext., Ames.

Penas, E.J., R.A. Wiese, R.W. Elmore, G.W. Hergert, and R.S. Moomaw. 1990. Soybean chlorosis studies on high $\mathrm{pH}$ bottomland soils. Inst. Agric. Nat. Res. Bull. 312. Univ. of Nebraska, Lincoln.

Rai, D. 1988. Interaction response of Glomus albidus and Cicer rhizobium strains on iron uptake and symbiotic N2 fixation in calcareous soil. J. Plant Nutr. 11:863-869. doi:10.1080/01904168809363851

Rogovska, N.P., A.M. Blackmer, and A.P. Mallarino. 2007. Relationships between soybean yield, soil $\mathrm{pH}$, and soil carbonate concentration. Soil Sci. Soc. Am. J.71:1251-1256. doi:10.2136/sssaj2006.0235

Rotaru, V., and T.R. Sinclair. 2009. Influence of plant phosphorus and iron concentrations on growth of soybean. J. Plant Nutr. 32:1513-1526. doi:10.1080/01904160903093828

SAS Institute. 2010. The SAS system for Windows. Release 9.2. SAS Inst., Cary, NC.

Starling, M.E., C.W. Wood, and D.B. Weaver. 1998. Starter Nitrogen and growth habit effects on late planted soybeans. Agron. J. 90:658-662. doi:10.2134/ agronj1998.00021962009000050015x

Terra, J.A., J.N. Shaw, D.W. Reeves, R.L. Raper, E. van Santen, E.B. Schwab, and P.L. Mask. 2006. Soil management and landscape variability affects field-scale cotton productivity. Soil Sci. Soc. Am. J.70:98-107. doi:10.2136/sssaj2005.0179

Terry, R.E., and V.D. Jolley. 1994. Nitrogenase activity is required for the activation of iron-stress response in iron-inefficient T203 soybean. J. Plant Nutr. 17:1417-1428. doi:10.1080/01904169409364816

Warncke, D., and J.R. Brown. 1998. Potassium and other basic cations. In: J.R. Brown, editor, Recommended chemical soil test procedures for the North Central Region. North Central Reg. Res. Publ. 221 (Rev.), SB 1001. Missouri Agric. Exp. Stn., Columbia. p. 31-34. 
Watson, M.E., and J.R. Brown. 1998.pH and lime requirement. In: Recommended chemical soil test procedures for the North Central Region.” North Central Regional Publ. 221 (Rev.). Univ. of Missouri Agric. Exp. Stn., Columbia. p. 13-16.

Whitney, D.A. 1998a. Micronutrients: Zinc, iron, manganese, and copper. In: Recommended chemical soil test procedures for the North Central Region.” North Central Regional Publ. 221 (Rev.). Univ. of Missouri
Agric. Exp. Stn., Columbia. p. 41-44.

Whitney, D.A. 1998b. Soil salinity. In: Recommended chemical soil test procedures for the north central region. NCR-13 Publ. 221. Missouri Agric. Exp. Stn. SB 1001. Univ. of Missouri, Columbia. p. 59-60.

Wiersma, J.V. 2010. Nitrate-induced iron deficiency in soybean variety with varying iron-stress responses. Agron. J. 102:1738-1744. doi:10.2134/ agronj2010.0240 